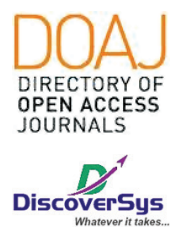

Published by DiscoverSys

\section{Profil pioderma pada anak usia 0-14 tahun di Rumah Sakit Umum Pusat (RSUP) Sanglah, Denpasar periode Juni 2015-2016}

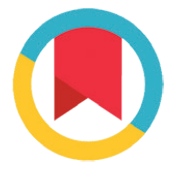

CrossMark

\author{
Dewa Ayu Agung Dwita Arthaningsih, ${ }^{1 *}$ Ni Luh Putu Ratih Vibriyanti Karna ${ }^{2}$
}

\begin{abstract}
Background: Pyoderma is a skin infection caused by bacteria Staphylococcus, Streptococcus, or both of it. Pyoderma often experienced by children which caused he skin resistance against the invasion of pathogenic germs, which not perfect as ts. Pyoderma morbidity in pediatric patients still occurs, especially in developing countries with tropical climates. This study aims to determine the pyoderma profile among children 0-14 years old at Sanglah General Hospital, Denpasar, in June 2015-2016 period.

Methods: A cross-sectional descriptive design using a retrospective approach was conducted in this study. Samples were determined using total sampling technique and this sample using pediatric patients aged 0-14 years in Sanglah General Hospital periods June 2015 to June 2016 who had pyoderma. The data obtained in this study were analyzed descriptively using SPSS version 17 for Windows.
\end{abstract}

Results: The results founded that there were 347 admissions, 53 patients suffering from pyoderma in Sanglah General Hospital. The majority of patients aged $\leq 4$ years were 31 patients (58.5\%), followed by the sex of the male as many as 34 patients $(64.2 \%)$, diagnosis of bullous impetigo 27 patients (50.9\%) and the location of lesions on the head of 32 patients (60.4\%). Positive results of gram-positive coccus examination were 28 patients (52.8\%) followed by the majority of patients getting a combination of topical and systemic antibiotics were 42 patients (79.2\%).

Conclusion: According to the data analysis and discussion, it can be concluded that the incidence of pyoderma in children is still quite a lot happening in Sanglah General Hospital during June 2015-2016 period.
1Program Studi Pendidikan Dokter, Fakultas Kedokteran, Universitas Udayana, Denpasar, Indonesia ${ }^{2}$ Bagian IImu Kesehatan Kulit dan Kelamin, Fakultas Kedoteran, Universitas Udayana, Denpasar, Indonesia

"Korespondensi:

Dewa Ayu Agung Dwita

Arthaningsih; Program Studi

Pendidikan Dokter, Fakultas

Kedoteran, Universitas Udayana,

Denpasar, Indonesia;

dwitaarthaningsih@gmail.com

Diterima: 11-06-2019

Disetujui: 03-01-2020

Diterbitkan: 03-03-2020
Keywords: Pyoderma, children, profile, Sanglah General Hospital

Cite This Article: Arthaningsih, D.A.A.D., Karna, N.L.P.R.V. 2020. Profil pioderma pada anak usia 0-14 tahun di Rumah Sakit Umum Pusat (RSUP) Sanglah, Denpasar periode Juni 2015-2016. Intisari Sains Medis 11(1): 22-27. D0I: 10.15562/ism.v11i1.520

\section{ABSTRAK}

Latar Belakang: Pioderma merupakan infeksi kulit yang disebabkan oleh kuman staphylococcus, streptococcus, atau oleh keduanya. Pioderma sering dialami anak-anak, karena daya tahan kulit terhadap invasi kuman pathogen belum sesempurna orang dewasa. Angka morbiditas pioderma pada pasien anak masih cukup terjadi terutama di negara berkembang dengan iklim tropis. Tujuan dari penelitian ini adalah ntuk mengetahui profil pioderma pada anak usia 0-14 tahun di Rrumah Sakit Umum Pusat Sanglah Denpasar periode Juni 2015- Juni 2016.

Metode: Penelitian ini menggunakan studi potong lintang deskriptif dengan desain penelitian retrospektif. Sampel ditentukan dengan menggunakan teknik total sampling, dalam sampel ini yang digunakan adalah pasien anak yang berusia 0-14 tahun di Rumah Sakit Umum Pusat Sanglah Denpasar periode Juni 2015- Juni 2016 yang mengalami pioderma. Data yang diperoleh dalam penelitian ini dianalisis secara deskriptif menggunakan SPSS versi 17 untuk Windows.

Hasil: Hasil penelitian secara deskriptif menunjukan bahwa dari 347 kunjungan, 53 pasien yang menderita pioderma di Rumah Sakit Umum Pusat Sanglah Denpasar. Sebagian besar pasien berusia $\leq 4$ tahun sebanyak 31 pasien (58.5\%), diikuti dengan jenis kelaminl laki-laki sebanyak 34 pasien (64.2\%), diagnosis impetigo bulosa 27 pasien (50.9\%) dan lokasi lesi pada kepala yaitu 32 pasien (60.4\%). Hasil positif pemeriksaan kokus gram positif sebanyak 28 pasien (52.8\%) diikuti dengan sebagian besar pasien mendapatkan kombinasi topikal dan antibiotik sistemik adalah 42 pasien (79.2\%).

Kesimpulan: Berdasarakan hasil analisis data dan pembahasan, maka dapat disimpulkan bahwa insidens pioderma pada anak masih cukup banyak terjadi di Rumah Sakit Umum Pusat Sanglah periode Juni 2015-2016.
Kata kunci: Pioderma, anak, profile, RSUP Sanglah

Cite Pasal Ini: Arthaningsih, D.A.A.D., Karna, N.L.P.R.V. 2020. Profil pioderma pada anak usia 0-14 tahun di Rumah Sakit Umum Pusat (RSUP) Sanglah, Denpasar periode Juni 2015-2016. Intisari Sains Medis 11(1): 22-27. D0I: 10.15562/ism.v11i1.520 


\section{PENDAHULUAN}

Kulit adalah organ yang esensial dan vital serta merupakan cermin kesehatan dan kehidupan. Kulit juga sangat kompleks dan sensitif, bervariasi pada keadaan iklim, umur, jenis kelamin, ras dan juga sangat bergantung pada lokasi tubuh. ${ }^{1}$ Kulit merupakan salah satu bagian tubuh manusia yang cukup sensitif terhadap berbagai macam penyakit. Bakteri, bersama-sama dengan jamur dan virus, dapat menyebabkan penyakit kulit. Penyakit kulit dapat terjadi pada semua kalangan dan sering dijumpai pada anak-anak, bahkan dikatakan merupakan masalah kesehatan masyarakat di negara berkembang. ${ }^{2}$

Di United Kingdom (UK), insidensi infeksi kulit pada anak-anak pada tahun 2005 adalah sekitar 75 per $100.000 .^{3}$ Menurut laporan dari World Health Organization pada Epidemiologi dan Manajemen Penyakit Kulit Umum pada Anak di Negara Berkembang pada tahun 2005, dilaporkan angka prevalensi yang tinggi untuk pioderma (kisaran prevalensi 0,2-35\%), tinea kapitis (1-19,7\%), skabies (0,2-24\%), gangguan kulit viral (0,4-9\%, terutama moluskum kontagiosum), pecikulosis kapitis (0-57\%), dermatitis (0-5\%), dan reaksi karena gigitan serangga (0-7,2\%). Anakanak menyajikan angka prevalensi lebih tinggi dari orang dewasa untuk pioderma terutama mereka yang di bawah 5 tahun. ${ }^{4}$

Disebutkan data dari Kelompok Studi Dermatologi Anak Indonesia (KSDAI) yang dikumpulkan dari 8 Rumah Sakit di Indonesia tahun 2011, pioderma pada anak menempati urutan pertama. Pada studi tersebut didapatkan 13, 86\% dari 8.919 kunjungan baru pasien kulit anak adalah pyoderma. ${ }^{5}$ Didapatkan bahwa jenis diagnosis pioderma terbanyak berturut-turut adalah impetigo dengan 31 pasien $(58,5 \%)$, furunkel dengan 11 pasien $(20,8 \%)$ folikulitis dengan 7 pasien $(13,2 \%)$, karbunkel dengan 2 pasien $(3,8 \%)$, untuk ektima dan selulitis niasing-masing 1 pasien $(1,9 \%)$ tapi erisipelas tidak terdapat kasus. ${ }^{5}$

Menurut penelitian Hazarika tahun 2012, dalam penelitian ini sebagian besar kasus dikelompok usia prasekolah (52\%), diikuti oleh kelompok umur sekolah 31\%). ${ }^{2}$ Ditemukan rasio laki-laki dan perempuan 1: 1,08. Perbandingan jenis kelamin yang dominan ini bertentangan dalam berbagai studi. Sebagian besar kasus pioderma primer datang selama musim panas dan lembab, termasuk trauma mikro yang disebabkan oleh gigitan serangga, mempengaruhi anak-anak rentan terhadap infeksi ini. ${ }^{2}$

Penyakit infeksi kulit masih merupakan masalah utama penyebab tingginya angka morbiditas pada anak-anak terutama di negara-negara berkembang dan wilayah beriklim tropis, termasuk di Indonesia. ${ }^{5}$ Penyakit infeksi ini sering dijumpai pada anak karena daya tahan kulit terhadap invasi kuman patogen belum sesempurna orang dewasa. Hal ini dikarenakan kulit anak-anak dibandingkan dengan kulit orang dewasa mempunyai struktur yang sedikit berbeda. ${ }^{1}$

Pioderma didefinisikan sebagai setiap penyakit kulit bernanah dan merupakan infeksi di epidermis dan dermis (misalnya, impetigo kontagiosa, impetigo bulosa, ektima, erisipelas, selulitis, dan lain sebagainya) atau di folikel rambut (misalnya folikulitis superfisialis, folikulitis profunda, furunkel, atau karbunkel). ${ }^{6}$ Mayoritas infeksi kulit ini disebabkan oleh Staphylococcus aureus dan Grup A Streptococcus (Hazarika, 2012). Pengobatan umum yang dapat diberikan yaitu sistemik dan topikal. Penelitian yang dilakukan oleh Lumataw PF dkk berdasarkan distribusi terapi pasien pioderma anak didapatkan bahwa terapi yang terbayak digunakan ialah terapi kombinasi antara antibiotik sistemik dan topikal yaitu sebanyak $35(66 \%){ }^{5}$

Meskipun penyakit kulit pada anak jarang bersifat letal, namun penyakit ini dapat memberikan dampak yang signifikan pada biaya pengobatan, dan stress psikologis. Untuk menilai faktor risiko penyakit kulit banyak hal yang harus dipertimbangkan antara lain ekologi dan lingkungan. Anak sangat sering terpapar oleh kondisi iklim dan kondisi sosial yang menjadi predisposisi bagi mereka untuk menderita infeksi kulit dan penyakit kulit lainnya. Berbagai faktor pencetus seperti iklim yang lembab, kemiskinan, menurunnya daya tahan seperti kekurangan gizi, anemia, penyakit kronik, dan neoplasma ganas turut berkontribusi terhadap kejadian pioderma pada anak. ${ }^{7}$ Telah ada penyakit lain di kulit karena terjadi kerusakan di epidermis, maka fungsi kulit sebagai pelindung akan terganggu sehingga memudahkan terjadinya infeksi. Serta kurangnya tingkat kebersihan terlibat dalam pengembangan pyoderma. ${ }^{8}$ Penyakit kulit pada anak dapat memberikan efek pada kualitas kehidupan, mengganggu hubungan antara keluarga dan hubungan sosial, mengganggu kegiatan seperti bermain, olahraga, dan sekolah, serta memberikan dampak pada perkembangan anak.

Pioderma pada anak masih menjadi permasalahan di negara-negara berkembang termasuk Indonesia. Melihat masih cukup banyak insiden angka morbiditas pioderma pada anak maka penulis tertarik untuk meneliti karakteristik Klinis pioderma pada anak usia 0-14 tahun di Rumah Sakit Umum Pusat Sanglah Denpasar pada periode Juni 2015-2016 berdasarkan usia, jenis kelamin, diagnosis, lokasi lesi, hasil pemeriksaan gram dan terapi yang diberikan. Penelitian ini diharapkan dapat memberikan gambaran profil pioderma rada 
anak usia 0-14 tahun di Rumah Sakit Umum Pusat Sanglah Denpasar periode Juni 2015-2016.

Metode

Penelitian ini dilakukan di Divisi Dermatologi Anak Poliklinik Penyakit Kulit dan Kelamin RSUP Sanglah Denpasar yang beralamat di Jalan Pulau Nias, Denpasar, Bali pada bulan Juli sampai Oktober 2016. Penelitian ini merupakan penelitian observasional yang menggunakan desain descriptive study secara retrospektif dimana pendekatan yang dipergunakan adalah potong lintang. Penelitian retrospektif adalah penelitian yang dilakukan pada peristiwa yang sudah terjadi. Peneliti mencari karakteristik klinis pioderma berdasarkan usia, jenis kelamin, diagnosis, lokasi terjadinya, hasil pemeriksaan gram dan terapi yang diberikan berdasarkan rekam medis pada periode juni 2015 sampai juni 2016.

Adapun beberapa variabel data penelitian yang dianalisis dicatat meliputi usia ( $\leq 4$ tahun atau $>4$ tahun), jenis kelamin (laki-laki atau perempuan), jenis diagnosis pioderma (impetigo bulosa, impetigi krustosa, folikulitis, karbunkel/furunkel, erisipelas, selulitis, atau ektima), distribusi lokasi

\section{Tabel 1 Karakteristik profil pioderma pada anak di RSUP Sanglah periode Juni 2015-2016}

\begin{tabular}{|c|c|c|}
\hline Variabel & Jumlah ( $\mathrm{N}=53)$ & Persentase (\%) \\
\hline \multicolumn{3}{|l|}{ Umur } \\
\hline$\leq 4$ tahun & 31 & 58,5 \\
\hline$>4$ tahun & 22 & 41,5 \\
\hline \multicolumn{3}{|l|}{ Jenis Kelamin } \\
\hline Laki-laki & 34 & 64,2 \\
\hline Perempuan & 19 & 35,8 \\
\hline \multicolumn{3}{|l|}{ Diagnosis Pioderma } \\
\hline Impetigo Bulosa & 27 & 50,9 \\
\hline Impetigo Krustosa & 8 & 15,1 \\
\hline Folikulitis & 6 & 11,3 \\
\hline Karbunkel/Furunkel & 1 & 1,9 \\
\hline Erisipelas & 2 & 3,8 \\
\hline Selulitis & 4 & 7,5 \\
\hline Ektima & 5 & 9,4 \\
\hline \multicolumn{3}{|l|}{ Hasil Kokus Gram positif } \\
\hline Tidak dilakukan & 3 & 5,7 \\
\hline Hasil tidak tercatat & 10 & 18,9 \\
\hline Positif & 28 & 52,8 \\
\hline Negatif & 12 & 22,6 \\
\hline \multicolumn{3}{|l|}{ Jenis Terapi } \\
\hline Topikal & 10 & 18,9 \\
\hline Antibiotik Sistemik & 1 & 1,9 \\
\hline Topikal +Antibiotik Sistemik & 42 & 79,2 \\
\hline
\end{tabular}

lesi (kepala, ekstremitas atas, ekstremitas bawah, atau seluruh tubuh), jenis terapi (topikal, antibiotik sistemik, atau kombinasi topikal dan antibiotik sistemik), maupun hasil pemeriksaan bakteri kokus gram positif (tidak dilakukan, hasil tidak tercatat, positif, atau negatif).

Seluruh data yang diperoleh kemudian dianalisis menggunakan piranti lunak SPSS versi 17 untuk Windows dimana ditampilkan dalam bentuk jumlah dan persentase berdasarkan parameter pemeriksaan tersebut.

\section{HASIL}

Penelitian ini telah dilakukan dengan mengambil data pada rekam medis di Rumah Sakit Umum Pusat Sanglah Denpasar. Berdasarkan data yang diperoleh selama periode Juni 2015 sampai Juni 2016 didapatkan jumlah sebanyak 53 sampel pasien anak yang mengalami pioderma. kunjungan pasien pioderma pada anak dapat dilihat total kunjungan pasien pioderma pada anak berjumlah 53 pasien (15.3\%) dari total kunjungan keseluruhan pasien anak adalah 347 pasien (Tabel 1).

Berdasarkan Tabel 1 diketahui bahwa rerata umur pasien pioderma pada pasien anak sejumlah 31 pasien berusia $\leq 4$ tahun $(58,5 \%)$ dan 22 pasien berusia $>4$ tahun (41,5\%). Jenis kelamin laki-laki terdiri dari 34 pasien (64.2\%) dan perempuan 19 pasien (35.8\%). Berdasarkan Tabel 1 diketahui juga bahwa distribusi jenis diagnosis pioderma pada anak didapatkan hasil sebagian besar adalah impetigo bulosa sejumlah 27 pasien (50.9\%), diikuti dengan impetigo krustosa 8 pasien $(15.1 \%)$, folikulitis 6 pasien (11.3\%), karbunkel/furunkel 1 orang pasien $(1.9 \%)$, erisipelas 2 pasien $(3.8 \%)$, selulitis 4 pasien $(7.5 \%)$, dan ektima 5 pasien (9.4\%).

Tabel 2 menunjukkan distribusi lokasi lesi pasien pioderma pada anak dibagi menjadi kepala, ektremitas atas, ekstremitas bawah dan seluruh tubuh. Didapatkan hasil penelitian yaitu dari 53 pasien sejumlah 21 pasien (39.6\%) mengalami lesi pada kepala. Sejumlah 16 pasien (30.2\%) dari 53 pasien mengalami lesi pada ekstremitas atas. Lokasi lesi pada ektremitas bawah sejumlah 9 pasien $(17.0 \%)$ dan terdapat 13 pasien $(24.5 \%)$ dari 53 pasien yang mengalami lesi pada seluruh tubuh (Tabel 2).

Berdasarkan Tabel 1 distribusi hasil pemeriksaan kokus gram positif yaitu sejumlah 3 pasien (5.7\%) tidak dilakukan pemeriksaan. Hasil tidak tercacatat sejumlah 10 pasien (18.9\%). Hasil positif pada pemeriksaaan kokus gram positif sebanyak 28 pasien $(52.8 \%)$, dan menunjukan hasil negatif sebanyak 12 pasien (22.6\%). Distribusi jenis terapi dibagi menjadi topikal, antibotik sistemik, 
Tabel 2 Distribusi lokasi lesi pasien pioderma pada anak

\begin{tabular}{lcc}
\hline Lokasi Lesi & Jumlah $(\mathbf{N}=\mathbf{5 3})$ & Persentase $(\%)$ \\
\hline Kepala & & \\
$\quad$ Tidak Ada lesi & 32 & 60.4 \\
$\quad$ Ada lesi & 21 & 39.6 \\
Ekstremitas Atas & & \\
$\quad$ Tidak Ada lesi & 37 & 69.8 \\
$\quad$ Ada lesi & 16 & 30.2 \\
Ekstremitas Bawah & & \\
$\quad$ Tidak Ada lesi & 44 & 83.0 \\
$\quad$ Ada lesi & 9 & 17.0 \\
Seluruh Tubuh & & \\
$\quad$ Tidak Ada lesi & 40 & 75.5 \\
$\quad$ Ada lesi & 13 & 24.5 \\
\hline
\end{tabular}

\section{Tabel 3 Distribusi jenis terapi sistemik dan topikal yang diperoleh pada pasien anak dengan pioderma di RSUP Sanglah periode Juni 2015-2016}

\begin{tabular}{lcc}
\hline Variabel & Jumlah & Persentase (\%) \\
\hline Jenis terapi sistemik (N=43) & & \\
Amoksisilin & 8 & 18,6 \\
Sefadroksil & 18 & 41,9 \\
Cefixime & 5 & 11,6 \\
Eritromisin & 12 & 27,9 \\
Jenis terapi tropikal (N=52) & & \\
Natrium fusidat krim & 21 & 40,4 \\
Kompres $\mathrm{NaCl} 0,9 \%$ & 2 & 3,8 \\
Kompres $\mathrm{NaCl} 0,9 \%$ + natrium fusidat krim & 26 & 50,0 \\
Kompres $\mathrm{NaCl} 0,9 \%$ + gentamisin & 3 & 5,8 \\
\hline
\end{tabular}

dan kombinasi topikal + Antibiotik sistemik. Pada penelitian ini didapatkan untuk terapi topikal adalah 10 pasien (18.9\%), terapi AS (Antibiotik sistemik) adalah 1 pasien (1.9\%), dan AS + topikal 42 pasien $(79.2 \%)$ dari total 53 pasien (Tabel 1).

Berdasarkan Tabel 3 distribusi jenis terapi dengan antibiotik sistemik pasien pioderma pada anak didapatkan bahwa amoksisilin 8 pasien (18.6\%), sefadroksil sejumlah 18 pasien (41.9\%), cefixime yaitu 5 pasien (11.6\%), eritromisin sejumlah 12 pasien (27.9\%) dengan total 43 pasien dengan terapi antibiotik sistemik. Distribusi terapi topikal pada penelitian ini yaitu 21 pasien $(40.4 \%)$ dengan natrium fusidat krim, 2 pasien (3.8\%) kompres $\mathrm{NaCl} 0,9 \%$. Ada 26 pasien (50.0\%) dengan kompres $\mathrm{NaCl} 0,9 \%+$ natrium fusidat krim, dan kompres $\mathrm{NaCl} 0,9 \%$ + gentamisin adalah 3 pasien (5.8\%) dengan jumlah 52 pasien pada penelitian ini yang menggunakan terapi topikal (Tabel 3).

\section{PEMBAHASAN}

Sampel yang diambil pada penelitian ini adalah pasien pioderma pada anak berusia 0 sampai 14 tahun yang berobat di Rumah Sakit Umum Pusat Sanglah Denpasar periode Juni 2015 sampai Juni 2016. Berdasarkan data yang ada, total kunjungan keseluruhan pasien anak dalah 347 pasien dan sejumlah 53 pasien (15.3\%) yang didiagnosis pioderma. Pada penelitian sebelumnya di RSUP Prof. Dr. R. D. Kandou Manado di divisi Dermatologi anak dari total kunjungan keeluruhan pasien anak adalah 321 terdapat 53 pasien $(16,51 \%)$ pada tahun 2012. ${ }^{5}$ Dan pada tahun 2006 sampai 2008 diketahui 90 pasien (2006), 117 pasien (2007), dan 58 pasien (2008) dan penelitian yang sama oleh peneliti berbeda pada tahun 2009 sampai 2011 terdapat 151 total kasus pioderma pada anak. ${ }^{5} \mathrm{Hal}$ ini menunjukkan bahwa insidens pioderma pada anak masih cukup banyak terjadi.

Distribusi data menurut umur menunjukan bahwa umur $\leq 4$ tahun yang paling banyak mengalami pioderma, sekitar $58.5 \%$ dan umur $>4$ tahun yaitu $41.5 \%$. Didapatkan hal yang sama pada penelitian yang dilakukan di RSU Dr. Soetomo Surabaya periode 2008 sampai 2010 umur yang paling sering adalah kelompok umur 1-4 tahun. ${ }^{9}$ Pada anak yang berusia lebih tua dan kelompok umur usia pra-sekolah juga sekolah memiliki faktor predisposisi yang memudahkan mereka terkena pioderma. Anak-anak tersebut mulai mengenal lingkungan dan bereksplorasi dengan alam sekitar. Kebiasan bermain berkelompok dan jenis permainan,dapat mempermudah masuknya bakteri patogen yang dapat memperburuk keaadaan kulit pada anak.

Hasil penelitian ini berdasarkan distribusi jenis kelamin menunjukan bahwa laki-laki lebih banyak megalami pioderma. Penelitian yang dilakukan di Gauhati Medical Collage \& Hospital, Guwahati dari Agustus 2005 - Juli 2006 didapatkan penderita perempuan lebih banyak daripada laki-laki yaitu perempuan $52 \%$ dan laki-laki $48 \%$. Dapat dilihat bahwa infeksi pioderma bisa dialami oleh laki-laki dan perempuan. ${ }^{2}$

Jenis diagnosis pioderma pada anak pada penelitian ini didapatkan jumlah terbanyak yaitu impetigo bulosa. Penelitian di rumah sakit lain juga menunjukan hasil bahwa impetigo bulosa paling banyak dijumpai, di RSUP Prof. Dr. R. D. Kandou Manado tahun 2012 icunjukan bahwa impetigo bulosa adalah kasus terbanyak yaitu $30.2 \% .^{5} \mathrm{Di}$ Gauhati Medical Collage \& Hospital, Guwahati juga menunjukan hal yang sama dimana impetigo bulosa adalah jenis diagnosis pioderma pada anak tebanyak dengan $29.4 \%{ }^{2}$ 
Hasil penelitian ini berdasarkan distribusi lokasi lesi menunjukkan angka kejadian terbanyak pada kepala dimana termasuk bagian wajah, diiikuti pada bagian ekstremitas atas, menyebar pada seluruh tubuh, dan pada bagian ektremitas atas bawah adalah $17.0 \%$. Menurut Andrew's, lesi pioderma biasanya terjadi pada bagian wajah, kulit kepala kemudian juga pada leher, ketiak, punggung, ataupun bagian ektremitas atas dan bawah. ${ }^{10}$ Pada penelitian di RSUD Dr. Soetomo Surabaya periode 2008 sampai 2010 juga menunjukan bahwa lokasi lesi terbanyak adalah kepala yaitu $26.5 \% .{ }^{9}$

Hasil pemeriksaan kokus gram positif dalam penelitian ini didapatkan positif kokus gram positif adalah $52.8 \%$, dan pemeriksaan kokus gram positif menunjukan hasil negatif yaitu $22.6 \%$ namun ada beberapa data yng tidak mencatat hasil dan beberapa pasien yang tidak dilakukan pemeriksaan karena alasan keluarga menolak dilakukan pemeriksaan gram. Didapatkan hasil serupa pada penelitian yang dilakukan sebelumnya, dengan $74.3 \%$ disebabkan oleh staphylococcus aureus. ${ }^{2}$ Penelitian yang juga dilakukan oleh Kakar dkk pada tahun 1999 juga menunjukan bahwa sebanyak 48\% disebabkan oleh Staphylococcus aureus dan 36\% oleh Streptococcus beta-hemolyticus. Untuk kombinasi keduanya menunjukan hasil $16 \%{ }^{11}$ Pada penelitian ini hal tersebut tidak dijumpai karena tidak dilakukan kultur dari dasar lesi.

Distribusi terapi yang diberikan pada pasien anak usia 0 sampai 14 tahun yang menderita pioderma di Rumah Sakit Umum Pusat Sanglah Denpasar periode Juni 2015 sampai Juni 2016 dapat disimpulkan bahwa penggunaan obat untuk terapi pioderma yang paling sering diberikan adalah terapi kombinasi antara antibiotik sistemik dan topikal yaitu $79.2 \%$, kemudian untuk pemberian antibiotik topikal saja yaitu $18.9 \%$, dan dengan pemberian antibiotik sistemik saja adalah $1.9 \%$. Ini juga sesuai dengan penelitian yang sebelumnya dilakukan oleh beberapa peneliti berbeda. ${ }^{5}$ Dikarenakan prinsip pemberian terapi antibiotik sistemik atau topikal berdasarkan pada hasil efloresensi kulit pasien berbentuk soliter atau multiple. Dimana pada penelitian ini didapatkan bahwa pada pasien dengan lesi soliter diberikan terapi topikal saja dan untuk pasien yang mengalami lesi multiple diberikan antibiotik sistemik dan juga topikal.

Pemberian terapi antibiotik sistemik didapatkan bahwa antibiotik sefadroksil yaitu $41.9 \%$ dan ini artinya memiliki jumlah terbanyak. Diikuti etritromisin 27.9\%, amoksisilin $18.6 \%$ dan Cefixime 11.6\%. Hasil berbeda didapatkan pada penelitian yang dilakukan oleh Dewi D. K di RSU Dr. Soetomo Surabaya tahun 2002 sampai 2006 menunjukan antibiotik yang paling sering digunakan adalah eritromisin. Menurutnya eritromisin lebih baik dalam etanol dan pelarut organic sehingga terdifusi dengan baik. ${ }^{9}$ Pada penelitian ini sefadroksil yang merupakan golongan sefalosporin dapat diberikan pada pioderma yang berat atau yang tidak memberi respon dengan obat-obatan yang lainnya, dan ada empat generasi yang berkhasiat untuk kuman gram positif ialah generasi I juga generasi IV, dan sefadroksil adalah contoh dari generasi I. ${ }^{12}$

Terapi topikal pada penelitian ini didapatkan yang paling sering diberikan adalah kombinasi kompres $\mathrm{NaCl} 0,9 \%$ + natrium fusidat krim yaitu sebanyak $50.0 \%$, selanjutnya yaitu dengan hanya pemberian natrium fusidat sebanyak $40.0 \%$, kombinasi $\mathrm{NaCl} 0,9$ + gentamisin yaitu 5.8\% dan pemberian $\mathrm{NaCl}$ 0,9\% dengan hasil 3.8\%. Prinsip terapi topikal kulit adalah basah dengan basah, kering dengan kering sesuai ph kulit.. Jika luka basah maka dipakai kompres $\mathrm{NaCl}$, kemudian kompres yang seharusnya untuk pioderma atau terjadi sutau infeksi serta lukanya kotor biasanya digunakan kompres antiseptik biasanya rivanol. ${ }^{12}$ Akan tetapi pada penelitian ini yang digunakan adalah $\mathrm{NaCl}$ 0,9\% karena rivanol sudah tidak digunakan lagi karena sifatnya yang mengiritasi kulit, dipakai $\mathrm{NaCl}$ karena ph-nya paling fisiologis mendekati cairan tubuh.

\section{KESIMPULAN}

Hasil penelitian ini menunjukkan bahwa profil pyoderma pada anak usia 0-14 tahun selama periode Juni 2015-2016 yang dilakukan di RSUP Sanglah sebagian besar berusia kurang dari 4 tahun, berjenis kelamin laki-laki, memiliki diagnosis impetigo bulosa, lokasi lesi dominan pada daerah kepala, terinfeksi bakteri kokus gram positif, serta mendapatkan kombinasi pengobatan topical dan antibiotik sistemik.

\section{KONFLIK KEPENTINGAN}

Tidak terdapat konflik kepentingan dalam penulisan laporan penelitian ini

\section{ETIKA PENELITIAN}

Penelitian ini telah mendapat persetujuan etik dari Komisi Etik Fakultas Kedokteran Universitas Udayana, Bali sebelum penelitian berjalan

\section{PENDANAAN}

Tidak ada 


\section{KONTRIBUSI PENULIS}

Dewa Ayu Agung Dwita Arthaningsih bertanggung jawab dalam perencanaan penelitian, pembuatan konsep penelitian, pencarian data, analisis data penelitian, hingga interpretasi hasil penelitian. Sedangkan Ni Luh Putu Ratih Vibriyanti Karna bertanggung jawab sebagai pembimbing dalam penelitian ini.

\section{DAFTAR PUSTAKA}

1. Wysocki AB. Skin anatomy, physiology, and pathophysiology. Nurs Clin North Am. 1999;34(4):777-97.

2. Hazarika N. A Clinico-Epidemiological Study of Pyoderma in Children. Nat J Res Com Med.2012;1(4):178 -241

3. Livermore DM, Mushtaq S, Warner M, James D, Kearns A, Woodford N. Pathogens of skin and skin-structure infections in the UK and their susceptibility to antibiotics, including ceftaroline. J Antimicrob Chemother. 2015;70(10):2844-53.

4. World Health Organization. Epidemiology and Management of Common Skin Diseases in Children in Developing Countries. 2005. [Tersedia pada http://whqlibdoc.who.int/hq/2005/WHO_FCH_CAH_05.12_eng.pdf] [Diakses tanggal 15 November 2015]

5. Lumataw PF, Pandaleke H, Suling PL. Profil Pioderma pada anak di poliklinik kulit dan kelamin RSUP Prof Dr. R. D. Kandou Manado periode tahun 2013-2015. Jurnal e-Clinic (eCl). 2016;4(2):1-7
6. Ahn C, Negus D, Huang W. Pyoderma gangrenosum: a review of pathogenesis and treatment. Expert Rev Clin Immunol. 2018;14(3):225-233.

7. Braswell SF, Kostopoulos TC, Ortega-Loayza AG. Pathophysiology of pyoderma gangrenosum (PG): an updated review. J Am Acad Dermatol. 2015;73(4):691-8.

8. Mistik S, Uludag A, Kartal D, Cinar SL. Bacterial Skin Infections: Epidemiology and Latest Research. Turkish Journal of Family Medicine \& Primary Care. 2015;9(2):65-74.

9. Rahmawati, A. Pioderma superfisialis primer pada anak di unit rawat jalan kesehatan kulit \& kelamin RSUD Dr. Soetomo Surabaya periode 2008-2010. Berkala Ilmu Kesehatan Kulit dan Kelamin. 2012;24(1):7-13.

10. James WD, Berger T, Elston D, Neuhaus I. Andrews' Diseases of the Skin: Clinical Dermatology. [London]: Saunders/ Elsevier, 2011.

11. Kakar N, Kumar V, Mehta G, Sharma RC, Koranne RV. Clinico-bacteriological study of pyodermas in children. J Dermatol. 1999;26(5):288-93.

12. Djuanda A. Ilmu Penyakit Kulit Dan Kelamin. Edisi keenam. Balai Penerbit FKUI: Jakarta. 2013.

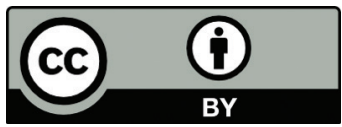

This work is licensed under a Creative Commons Attribution 